\title{
Impact of bioroughness on interfacial solute exchange in permeable sediments
}

\author{
M. Huettel ${ }^{1}$, G. Gust ${ }^{2}$ \\ ${ }^{1}$ Max-Planck-Institut für Marine Mikrobiologie, Fahrenheitstr. 1, W-2800 Bremen 33, Germany \\ ${ }^{2}$ Technische Universität Hamburg-Harburg, Arbeitsbereich Meerestechnik, Lauenbruch-Ost 1, W-2100 Hamburg 90, Germany
}

\begin{abstract}
We demonstrate the contribution of biogenic sediment microtopography, termed bioroughness, comprising all surface relief created by benthic organisms, on interfacial solute fluxes in permeable beds. Rhodamine-WT dye injected in sandy intertidal sediments revealed strong advective porewater replacement down to $5 \mathrm{~cm}$ sediment depth caused by small aggregates of mussel shells exposed to boundary layer flows. In a set of laboratory flume experiments we quantify the impact of various types of bioroughness elements on interfacial solute exchange and identify small-scale horizontal pressure gradients of $<1 \mathrm{~Pa} \mathrm{~cm}-1$ as the driving force for the advective processes. Roughness size, sediment permeability, and characteristics of the boundary layer flow determined magnitude and depth range of the resulting advective porewater flows, which provided a fast, conveyor-belt-type link between sediment layers as deep as $15 \mathrm{~cm}$ and the water column. Simulated bioroughness elements in natural sizes and abundances increased porewater fluxes in sandy sediment up to 7 -fold at subcritical flows (friction velocity $u_{0}<0.8 \mathrm{~cm} \mathrm{~s}^{-1}$ ) compared to smooth-bed fluxes. Advective porewater flows were associated with structures as small as $700 \mu \mathrm{m}$ at water flows as low as $3 \mathrm{~cm} \mathrm{~s}^{-1}$ and sediments with permeabilities of $K>3$ Darcy (D). Interfacial fluxes associated with protruding bioroughness exceeded those with recessed structures of comparable size. Elevated biogenic structures just above an undisturbed smooth surface, such as resting crabs, produced pressure patterns similar to those recorded for small mounds, and at an abundance of $17 \mathrm{~m}^{-2}$ increased dye flux up to 5 -fold relative to smooth control runs. Moving on 3-dimensional streamlines, bioroughness-driven advection is an important structuring process in permeable sediments, increasing the surface area of geochemical reaction zones and creating a variety of microenvironments for interstitial life. We conclude that roughness-related advective porewater processes play a key role in permeable sediments.
\end{abstract}

\section{INTRODUCTION}

Interfacial solute fluxes link the decomposition of organic matter in marine sediments to the production processes in the overlying water column (Berner 1976, Blackburn 1986, Wainright 1990). The products of organic matter mineralization are released into the water while oxygen, sulfate and other reactive solutes penetrate into the sediment, providing essential metabolites for both the sedimentary detrivore food chain (Fenchel 1970) and bacterial decomposition activities (Berner 1980, Jørgensen \& Sørensen 1985). Depending on sediment composition, water depth and site-specific fauna, diffusive transport of solutes (Berner 1976) as well as wave-induced flushing (Riedl et al. 1972, Malan \& McLachlan 1991) and bioturbation (Rhoads et al. 1977, Gust \& Harrison 1981, Aller 1982, Wheatcroft
1991) have been found to contribute to interfacial solute exchange. Of these solute pathways, only concentration-driven transport does not require fluid exchange and obeys the Fickian law of diffusion. In contrast, wave action and bioturbation enhance solute fluxes through advective fluid exchange between permeable sediments and the water column. Wave-induced orbital motions flush (and in the extreme can fluidize) the uppermost sediment layers (Riedl \& Machan 1972, Rutgers van der Loeff 1981), while ventilation or feeding currents created by endobenthic organisms, pumping water through individual burrows, can reach locally to depths $>100 \mathrm{~cm}$ (Pemberton et al. 1976, Aller \& Yingst 1985, Reichardt 1988, Huettel 1990).

This work focuses on the influence of biogenic microtopography, which we term bioroughness, on interfacial solute fluxes and microzonation in perme- 
able marine soft sediments under unidirectional flows. Abundant benthic life at all oceanic depths creates characteristic biogenic traces and topographies on the sediment surface and can alter sediment permeabilities vertically (Grassle et al. 1975, Rhoads \& Boyer 1982, Richardson et al, 1985). Burrow excavation, foraging, feeding traces and skeletal remains of benthic organisms produce abundant local relief ranging in height from fractions of a millimeter to several centimeters (Howard et al. 1977, Cacchione et al. 1987), as documented for abyssal depth by close-up stereophotographs on the Nova Scotian continental rise by Swift et al. (1985). Bioroughness provides not only most of the relief in marine soft bottoms (Laughton 1963, Heezen \& Hollister 1971) but is often also characterized by higher structural stability due to mucous binding of the sedimentary structures (Nowell et al. 1981, Taghon et al. 1984). An overview of typical surface structures in marine sediments is given by Heezen \& Hollister (1971); the impact of microtopography generated by physical processes on water flow near the sediment surface and energy dissipation in the bed is summarized in Sleath (1984).

The potential relevance of bioroughness is based on the Bernoulli principle (Schlichting 1979), whereby a water current moving along the sediment interface accelerates and decelerates locally upon passing small protrusions and depressions (irrespective of their biogenic or sedimentary origin). In all cases roughnessrelated local pressure gradients are generated (see Fig. 4.8. in Vogel 1981 and Fig. 3.8. in Denny 1988). In this work we investigate to what extent pressure gradients associated with various types of bioroughness can influence the exchange of porewater and solutes at the sediment-water interface of permeable sediments.

\section{METHODS}

The effect of bioroughness on interfacial solute exchange was investigated in a series of standardized experiments in a laboratory flume at flow velocities below the erosion threshold (flow speed $u<20 \mathrm{~cm} \mathrm{~s}^{-1}$ ). Light-colored quartz sand and porewater mixed with Rhodamine dye permitted visualization of the resulting interstitial fluid flow and allowed both comparison and quantification of interfacial bioroughness-related solute fluxes.

The open channel recirculating flume $(600 \mathrm{~cm}$ length, $32 \mathrm{~cm}$ width, $25 \mathrm{~cm}$ height) contained a $175 \mathrm{~cm}$ long, $15 \mathrm{~cm}$ deep sediment core spanning the flume width. Acrylic surfaces, mounted up- and downstream flush with the core, allowed undisturbed 2-dimensional boundary layer flow over the sediment surface. The current speed was controlled by a valve in the recirculation pipe, together with flume tilt and a heightadjustable sharp-crested weir at the downstream end of the flume. The water level was kept at $5 \mathrm{~cm}$ in the measuring section. A hot film sensor (Gust 1988) mounted on the downstream acrylic surface, recorded the friction velocity, $u .=(\tau / \rho)^{1 / 2}$ (where $\tau=$ bottom stress $\rho=$ fluid density), which agreed with the total shear stress calculated from slope measurements by the energy gradient method (Schlichting 1979). A row of 15 glass tubes, embedded vertically at equal depth in a $60 \mathrm{~cm}$ long section along the centerline of the sediment core, provided the ports for the measurement of horizontal pressure gradients when attached to a highly sensitive, inductive wet/wet differential pressure gauge.

To quantify the porewater flow, Rhodamine-WT dye was added to washed quartz sand (grain size $\phi=2.2$; compacted sediment permeability $K=15$ Darcy (D), porosity $=34.6 \%$ ) until the dye concentration in the porewater reached approximately $10 \%$ (adjusted by spectrophotometrical comparison with a reference sample). This mixture of sediment and dyed porewater was placed in the sediment trough in the downstream section of the flume. Edge and sidewall effects, which significantly increase interfacial solute fluxes in confined sediment cores exposed to water currents, were avoided by buffer zones of neutral, clean washed sediment of equal permeability along all edges of the sediment core (Huettel \& Gust 1992). The sediment was compacted by applying low-frequency vibrations during the filling process and subsequently carefully smoothed by sliding a $2 \mathrm{~m}$ long precision T-rod laterally across the sediment core. Sediment surfaces, with a resulting roughness smaller than $0.3 \mathrm{~mm}$, were newly prepared for each run and either provided the reference surfaces for flux control runs at different flow speeds, or formed the substrate on which the biogenic structures were established. Regular ripples of $0.5 \mathrm{~cm}$ amplitude and $6 \mathrm{~cm}$ wavelength, set up by creating bedload under supercritical flow for a short time period, provided an additional (this time hydrodynamically rough) reference surface.

We chose basic forms of common biogenic surface structures, with sizes and abundances similar to those found at a test site (see below) on an intertıdal flat at the island of Sylt, Germany (Table 1, column 1). The roughness elements were divided into 3 major categories: recessed, protruding and elevated structures. By means of templates, adequate replicas of funnels and mounds were generated for each individual run. Tubes $(0.6 \mathrm{~cm}$ diameter) made of rolled-up permeable gauze $(40 \mu \mathrm{m})$ represented polychaete burrows extending vertically from the surface down to $13 \mathrm{~cm}$ sediment depth. A coiled $7 \mathrm{~m}$ long nylon cord of $0.3 \mathrm{~cm}$ diameter, pressed into the sediment surface, produced the random, depressed pattern which simulated poly- 


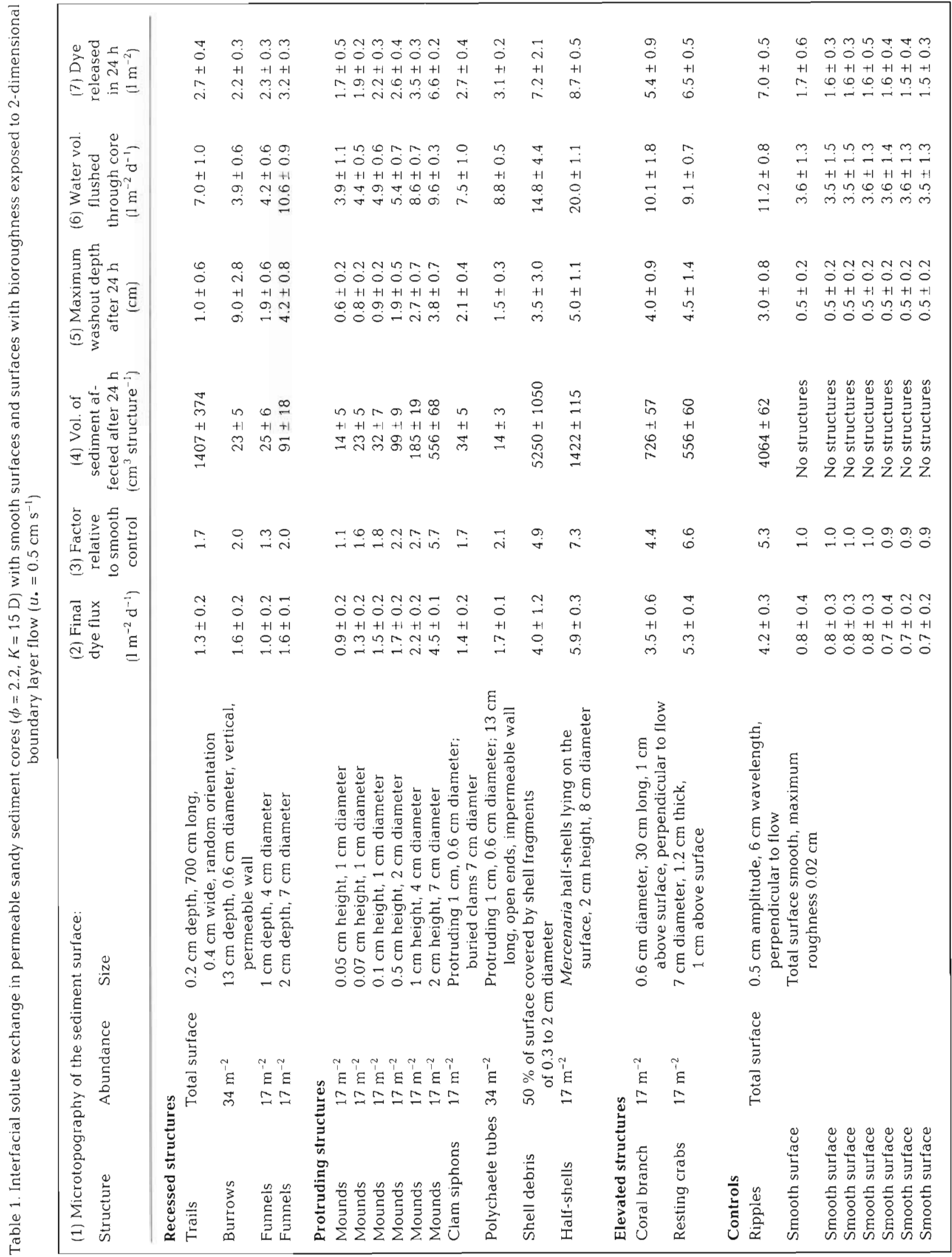


chaete and snail trails. Half-shells of the clam Mercenaria campechiensis $(7$ to $8 \mathrm{~cm}$ diameter, maximum $2 \mathrm{~cm}$ height) covering the surface established impermeable bioroughness elements. Buried clams extending their siphon were simulated using the same shells (though buried) with an attached small plastic tube of $0.6 \mathrm{~cm}$ outer diameter reaching $1 \mathrm{~cm}$ above the sediment surface. Shell debris composed of fragments 0.3 to $2 \mathrm{~cm}$ in diameter was randomly scattered on the sediment surface with a $50 \%$ coverage $\left(=1750 \mathrm{~cm}^{2}\right)$ of the core. Plastic tubes of $13 \mathrm{~cm}$ length and $6 \mathrm{~mm}$ diameter, placed vertically into the sediment and protruding $10 \mathrm{~mm}$ above the surface, simulated impermeable polychaete tubes. Elevated structures simulating resting crabs were made of PVC disks $(7.7 \mathrm{~cm}$ in diameter, $1.7 \mathrm{~cm}$ thick) supported by 4 wooden sticks (or copper wire) of $2 \mathrm{~mm}$ diameter holding the disk $1 \mathrm{~cm}$ above the sediment surface. Staggered locations and maximized distances of the individual biogenic surface elements comprising a roughness field kept flow interferences from vortex streets to a minimum.

Each experiment began with the flume pump being started, recirculating $280 \mathrm{l}$ of fresh water through the flume. The flow speed in the flume was adjusted to generate the desired wall shearing stress at the sediment-water interface and is expressed henceforth as friction velocity, $u$. Subsequently, $3 \mathrm{ml}$ flume water samples $(\mathrm{n}=3)$ were collected in time intervals ranging from $5 \mathrm{~min}$ in the initial phase of the experiments to $2 \mathrm{~h}$ in the final phase. The volume of released porewater was determined from spectrophotometrical measurements of the Rhodamine content of the water samples and subsequent comparison with samples from runs without sediment but with known dye concentration in the same volume of flume water. Longitudinal and lateral dissection of the sediment cores after the experiments revealed the patterns and penetration depths of flume water and dye washout. Regular patterns of vertical dye stripes and dots, produced by injecting Rhodamine with a syringe into the sediment, allowed us to determine the paths and speeds of bioroughness-related advective porewater flows.

\section{RESULTS}

The experiments were designed to establish firstly the link between boundary-layer hydrodynamics and interfacial fluxes of a conservative tracer for the smooth control cores of permeable sediments. After introduction of these results we describe the advective processes observed in sediment cores with protruding, elevated and recessed bioroughness elements. A comparison of the interfacial dye fluxes recorded in cores without and with bioroughness concludes this section.
Measurements of vertical velocity profiles in the upand downstream sections of a smooth control core revealed almost fully developed boundary layer flow (the vertical flow profile did not change in the downstream direction) with a viscous sublayer of $0.1 \mathrm{~cm}$ thickness at a friction velocity of $0.5 \mathrm{~cm} \mathrm{~s}^{-1}$. Although the grain roughness of the smooth reference surfaces was limited to $k_{\mathrm{s}}<0.3 \mathrm{~mm}$ (corresponding to 1 grain size diameter), interaction of the boundary layer flow with this remaining surface micro-roughness added to the diffusive dye release by flushing the uppermost sediment layer and steepening the dye concentration gradient in the porewater, evidenced after each run by the presence of a thin uniform surface layer of sand immersed in undyed porewater topping the underlying red sediment core. In $24 \mathrm{~h}$ runs, the depth of this flushed upper layer measured $0.2 \pm 0.1 \mathrm{~cm}$ in fine sand $(\phi=2.2)$ at a friction velocity of $0.3 \mathrm{~cm} \mathrm{~s}^{-1}$, and increased to $1.0 \pm 0.2 \mathrm{~cm}$ at $u .=0.8 \mathrm{~cm} \mathrm{~s}^{-1}$. The associated dye fluxes grew from $0.2 \pm 0.05 \mathrm{l} \mathrm{m}^{-2} \mathrm{~d}^{-1}$ in stagnant water to $1.4 \pm 0.31 \mathrm{~m}^{-2} \mathrm{~d}^{-1}$ at $u .=0.8 \mathrm{~cm} \mathrm{~s}^{-1}$. Although the depth of this flushed layer showed an exponential increase with the permeability of the substratum, dye fluxes from fine silt $\left(1.4 \pm 0.2 \mathrm{l} \mathrm{m}^{-2} \mathrm{~d}^{-1}\right.$, $\left.\phi=6.6, K=3.4 \mathrm{D}, u .=0.3 \mathrm{~cm} \mathrm{~s}^{-1}\right)$, exceeded that from fine sand $\left(0.4 \pm 0.1 \mathrm{l} \mathrm{m}^{-2} \mathrm{~d}^{-1}, \phi=2.2, K=2.2 \mathrm{D}, u .=\right.$ $0.3 \mathrm{~cm} \mathrm{~s}^{-1}$ ), which may be attributed to the high porosity ( $81 \%$ vs $35 \%$ ) and lower tortuosity of the silt (diatom powder) with ensuing increased diffusive transport.

In contrast to the horizontally uniform decolorization of the top layer of the smooth control cores, biogenic surface structures of all 3 categories (recessed, protruding and elevated) produced characteristic non-homogeneous dye washout patterns at the sediment surface and in the upper sediment layer as the result of boundary layer flows (Figs. 1 \& 2a). Dyed porewater emerging from the sediment (Fig. 2b) and the deformation of dyed vertical porewater stripes (Fig. 2c) revealed an immediate response of the interstitial fluid to the flume flow with distinct areas of flume water intrusion and porewater upwelling developing within 1 to $10 \mathrm{~min}$. The porewater moved along 3-dimensional flow paths, causing vertical as well as horizontal fluid exchange in the sediment. With the selected abundance of biogenic surface structures representing common natural densities, the entire upper sediment layer was affected by these advective processes, which caused increased interfacial solute fluxes comparable to those recorded in the sediment surfaces with ripples. Protruding and elevated surface structures exposed to flow generated dye fluxes which exceeded those of recessed biogenic structures of comparable size (Table 1 , columns $2 \& 3$ ). 
Fig. 1 Washout patterns caused by biogenic surface structures in a sandy sediment core $(\phi=2,2)$ with dyed porewater exposed to boundary layer flow $\left(u .=0.5 \mathrm{~cm} \mathrm{~s}^{-1}\right)$ for $24 \mathrm{~h}$. Light areas indicate zones of dye washout, dark areas dye upwelling. Flow direction from right to left

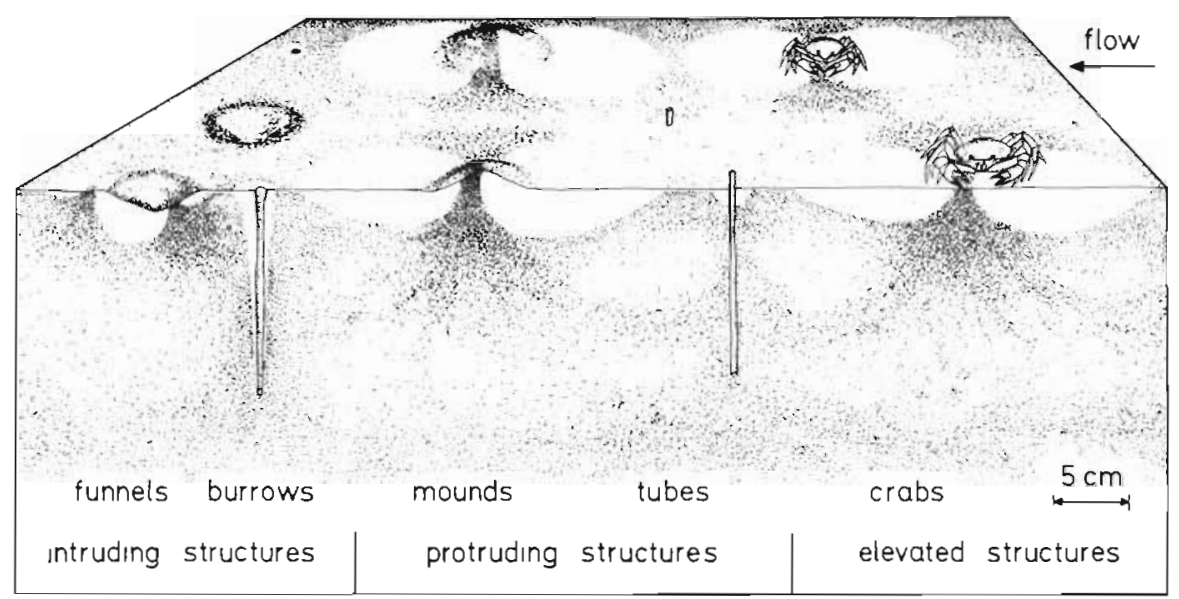

The driving forces for these advective porewater flows in permeable sediments are small pressure gradients which develop according to Bernoull's principle when the boundary layer flow moves past surface roughness structures. Water approaching even small elevations on the sediment surface is deflected upand sidewards locally, thus generating high-pressure areas at the upstream base of the obstructions $(+1.6 \mathrm{~Pa}$, $1.7 \mathrm{~cm}$ mound, $u .=0.5 \mathrm{~cm} \mathrm{~s}^{-1}$ ) and consequently horlzontal pressure gradients relative to the undisturbed (smooth) case (Fig. 3b). This gradient drives water into the permeable sediment. The intruding water flushes the sediment within a hemispherical zone in front of the elevation, with resulting porewater flows directed both upstream and downstream as well as laterally from the convergence area where flume water infiltrates the sediment. On top of a roughness element (biogenic structure) the flow then accelerates due to the reduced cross-sectional area of the flow, which results in decreased pressure above the elevation, evidenced by the negative peak of the pressure distribution curve presented in Fig. $3 \mathrm{~b}(-2 \mathrm{~Pa}, 1.7 \mathrm{~cm}$ mound, $\left.u .=0.5 \mathrm{~cm} \mathrm{~s}^{-1}\right)$. The ensuing negative pressure gradient pulls porewater from deeper sediment layers to the surface (Fig. 2b). A second high pressure area develops downstream of the obstruction where the expanding cross-section leads to decelerating flow with formation of eddies. Ensuing water intrusions at the downstream edge of the elevation again move in both upstream and downstream directions, flushing a second hemispherical sediment zone. Though not as deep, it is wider than the zone upstream of the mound. Mounds as small as $0.07 \mathrm{~cm}$ produced this characteristic dye washout pattern with a zone of upwelling porewater wedged between the 2 hemispherical flushing zones. Clam half-shells placed on the surface generated pressure and washout patterns almost identical to those found for mounds. The washout patterns in the reference core with sediment ripples were similar in the centerline transect to the patterns described for mounds, though stretched paralleling the ripples, and reached $3 \mathrm{~cm}$ into the sediment $(\phi=2.2$, $u_{\text {. }}=0.5 \mathrm{~cm} \mathrm{~s}^{-1}, \mathrm{t}=24 \mathrm{~h}$ ).

Fig. 4a depicts the evolution of the flushing process in a sediment core with mounds of $1.8 \mathrm{~cm}$ helght during an experimental run. The strong initial growth in washout depth and associated dye flux due to flushing of the uppermost sediment layer slowed down after approximately $5 \mathrm{~h}$. In sediment cores with mounds of $2.4 \mathrm{~cm}$ height, flume water intrusion reached as deep as $5 \mathrm{~cm}$ after $24 \mathrm{~h}$ at $u$. $=0.5 \mathrm{~cm} \mathrm{~s}^{-1}$, and was still increasing (Fig. 4b). The flushed hemispencal sediment volumes up- and downstream of each individual elevation totalled $700 \mathrm{~cm}^{3}$, whlle the affected surface areas covered $380 \mathrm{~cm}^{2}$ Flow past a mound of $2.5 \mathrm{~cm}$ height $\left(u .=0.7 \mathrm{~cm} \mathrm{~s}^{-1}\right.$ ) caused upwelling of porewater to the surface from a $2 \mathrm{~cm}$ thick horizontal layer of dyed porewater, establıshed at 13 to $15 \mathrm{~cm}$ sediment depth, within 24 h (Fig. 2b). Upward-as well as downward-directed porewater flows moved fastest in the top sediment layer (ca $1.5 \mathrm{~cm} \mathrm{~h}^{-1}$ at $2 \mathrm{~cm}$ depth with $\left.u .=0.7 \mathrm{~cm} \mathrm{~s}^{-1}, \phi=2.2\right)$ and at $8 \mathrm{~cm}$ depth still surpassed diffusive transport velocities 0.3 to $0.6 \mathrm{~cm} \mathrm{~d}^{-1}$ for the dye concentration gradients under consideration here) by a factor up to 100 (Fig. 5). Pressure gradients and advective porewater flows generated by mounds grew exponentially with therr size and the friction velocity at the sediment-water interface (Figs. 4b, c \& 6).

The elevated disk ('resting crab') produced pressure gradients and washoul patterns simlar to those observed in mounds of comparable size (Figs. $1 \& 3 a$, b) although the sediment surface proper remained smooth. Positive pressure relative to that at the ambient surface (maxımum $=+0.9 \mathrm{~Pa}$ ) was created by the elevated flow obstruction which forced flume water into the sediment upstream of the elevated disk and in a second high-pressure zone in the turbulent wake 
a

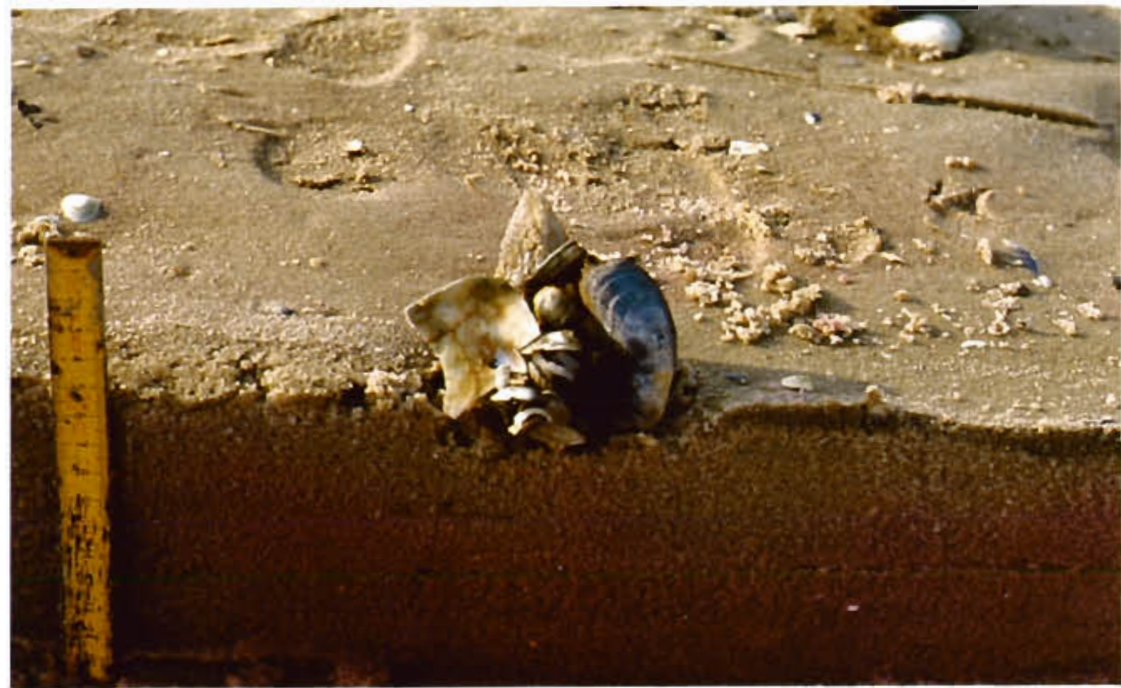

b

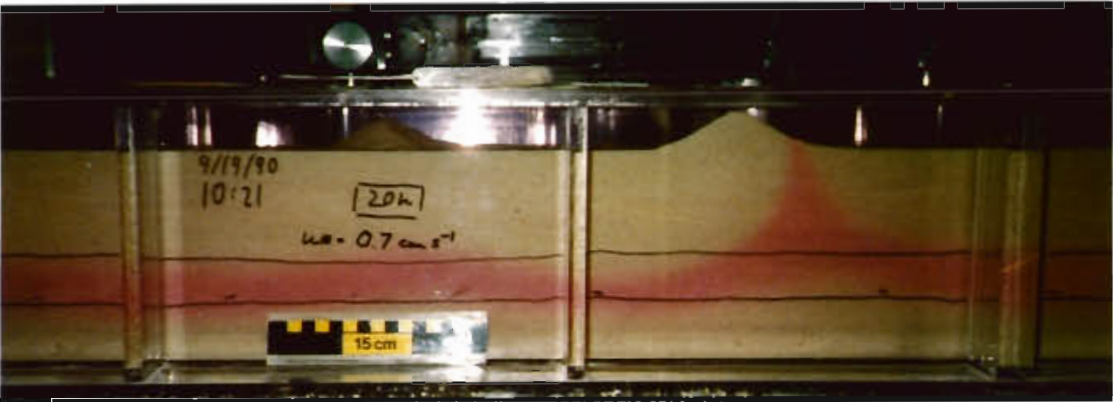

Fig. 2. (a) Dye washout pattern produced in situ by a small aggregation of Mytilus edulis exposed to tidal flow in an intertidal sand tlat on island Sylt $(\phi=2, t=6 \mathrm{~h}$, main flow direction from the right to the left). (b) Initially horizontal dye layer, drawn from $13 \mathrm{~cm}$ depth to the surface by the pressure gradients produced by a $2.5 \mathrm{~cm}$ mound during a $24 \mathrm{~h}$ run. The sidewall effect shifted the upwelling zone further downstream than observed in centerline cuts $(u s .=0.7 \mathrm{~cm}$ $\mathrm{s}^{-1}, \dot{\phi}=2.2$, flow direction from leit to right). (c) Evolution of the advective porewater flows associated with a mound ( $2 \mathrm{~cm}$ high) and a funnel $(2 \mathrm{~cm}$ deep) in permeable sandy sediment. The first picture was taken at the start of the experiment, the second after $3 \mathrm{~h}$. The sidewall effect shifted the upwelling zone of the mound further downstream ( $u \cdot=0.5 \mathrm{~cm} \mathrm{~s}^{-1}, \phi=2.2$,

flow direction from right to left)

C
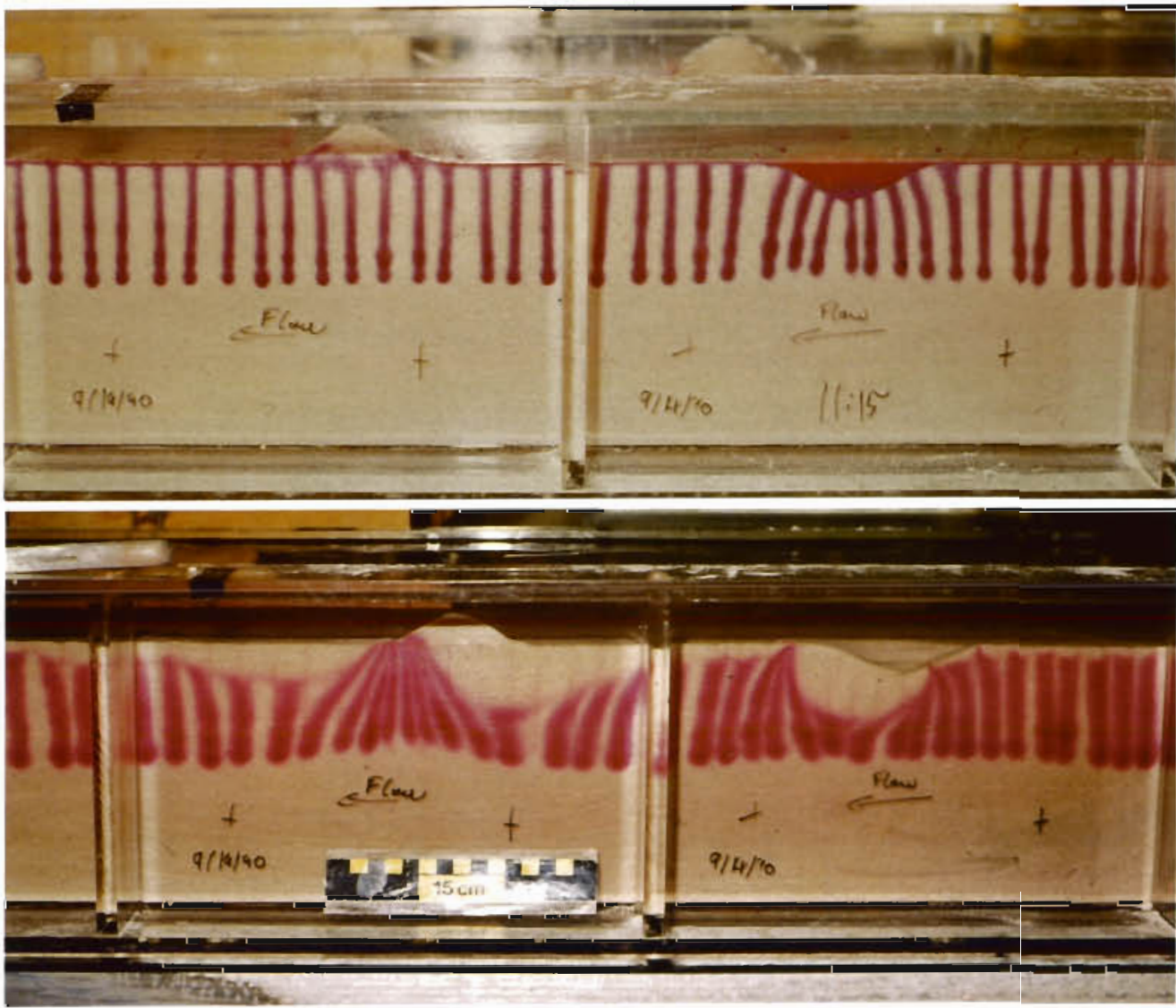
area downstream of the crab (Fig. 3a). A low-pressure area prevailed in the flow acceleration zone beneath the elevated disk where a red spot on the sediment surface revealed continuous porewater emergence $(-1.8 \mathrm{~Pa}$, disk diameter $5.1 \mathrm{~cm}$, disk thickness $1.7 \mathrm{~cm}$, disk height $1 \mathrm{~cm}$ maintained by 4 copper-wire legs).

For recessed topography (funnels) the velocity of the flow decreases and the pressure in the fluid increases when the local cross section expands. The opposite holds on the downstream side of a funnel, where the flow accelerates again, leading to a pressure decrease in the fluid. The resulting pressure pattern (Fig. 3c) generates porewater flows emerging at the upstream and downstream rims of the depression (Figs. $1 \& 2 \mathrm{c}$ ), while water intrudes at the downstream slope and bottom of the funnel, where the highest pressure increase was recorded $\left(0.7 \mathrm{~Pa}\right.$ at $u .=0.5 \mathrm{~cm} \mathrm{~s}^{-1}$; depth of funnel $1.3 \mathrm{~cm}$ ). Local pressure gradients flushing porewater advectively were recorded for depressions as shallow as $0.1 \mathrm{~cm}$ with $0.5 \mathrm{~cm}$ diameter, while the associated pressure gradient increased exponentially with growing depth of the depression (Fig. 6). Pressure gradients caused by a funnel of $1.9 \mathrm{~cm}$ depth drove flume water as deep as $4.2 \mathrm{~cm}$ into the sediment during a $24 \mathrm{~h}$ time period (Fig. $4 \mathrm{a}, \mathrm{u}_{\mathbf{0}}=0.5 \mathrm{~cm} \mathrm{~s}^{-1}$ ). At a friction velocity of $0.8 \mathrm{~cm} \mathrm{~s}^{-1}$, downward porewater velocities decreased from $9.6 \mathrm{~cm} \mathrm{~h}^{-1}$ in a $0.5 \mathrm{~cm}$ thick layer adjoining the downstream slope of a $2 \mathrm{~cm}$ deep funnel to $0.1 \mathrm{~cm} \mathrm{~h}^{-1}$ at $8 \mathrm{~cm}$ sediment depth (Fig. 5). The speed of porewater upwelling from layers as deep as $7 \mathrm{~cm}\left\{1 \mathrm{~cm} \mathrm{~h}^{-1}\right.$ at $7.3 \mathrm{~cm}$ depth for the $1.9 \mathrm{~cm}$ funnel at $u .=0.8 \mathrm{~cm} \mathrm{~s}^{-1}$ ) increased in the upper $2 \mathrm{~cm}$ of sediment. Although the washout patterns found in sediment cores with funnels reached as deep as those recorded for surfaces with mounds or crabs of similar size, the dye washout caused by funnels was mostly restricted to the sediment beneath the depressions; the flushed sediment volumes and surface areas affected by funnels were smaller by a factor of 6 to 7 than those found for protruding and elevated structures of comparable roughness volume (Fig. $4 \mathrm{a}, \mathrm{b}, \mathrm{c}$ ).

The uppermost section of burrows, which often end in small surface depressions and trails engraved in the sediment surface, interact with the boundary layer flow as described for the funnels. In our experiments, fluid exchange in the upper part of the burrows reached as deep as $9 \mathrm{~cm}$ in a $13 \mathrm{~cm}$ long burrow with $0.6 \mathrm{~cm}$ diameter at $u_{0}=0.5 \mathrm{~cm} \mathrm{~s}^{-1}$. The weak flow associated with this fluid exchange produced a halo of flushed sediment with $3 \mathrm{~cm}$ outer diameter around the burrows which diminished with depth (Fig. 1).

According to Bernoulli's principle, the pressure gradients produced by surface structures are also a function of the water depth (cross-sectional area of the water flow). To determine whether a higher water
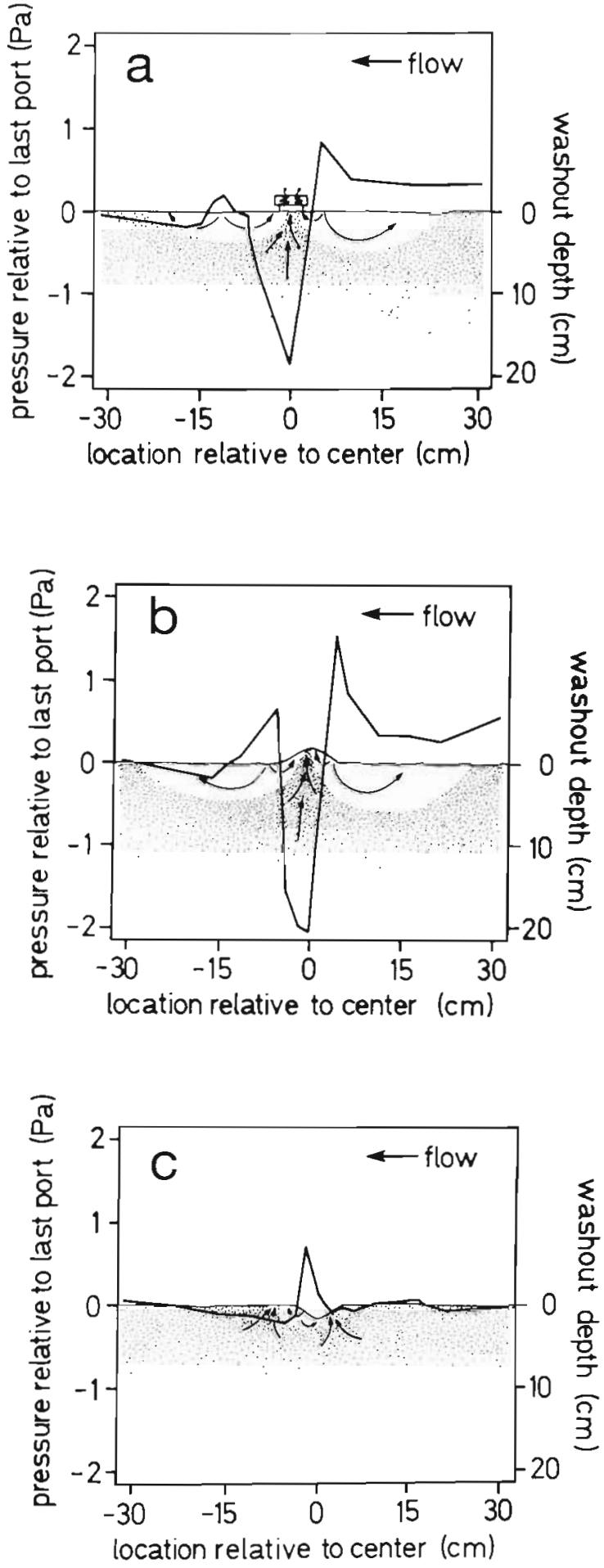

Fig. 3. Interfacial pressure distribution generated by an elevated (a: crab, $1.7 \mathrm{~cm}$ thick, $5.1 \mathrm{~cm}$ diam.), a protruding (b: mound, $1.7 \mathrm{~cm}$ height, $7 \mathrm{~cm}$ diam.) and a recessed (c: funnel, $1.3 \mathrm{~cm}$ deep, $7 \mathrm{~cm}$ diam.) bioroughness element at a friction velocity of $u .=0.5 \mathrm{~cm} \mathrm{~s}^{-1}$ Light areas indicate dye washout, arrows the streamlines of the advective porewater flows $(\phi=2.2, \mathrm{t}=24 \mathrm{~h})$. The last pressure port (reference port) is located at $-30 \mathrm{~cm}$ 

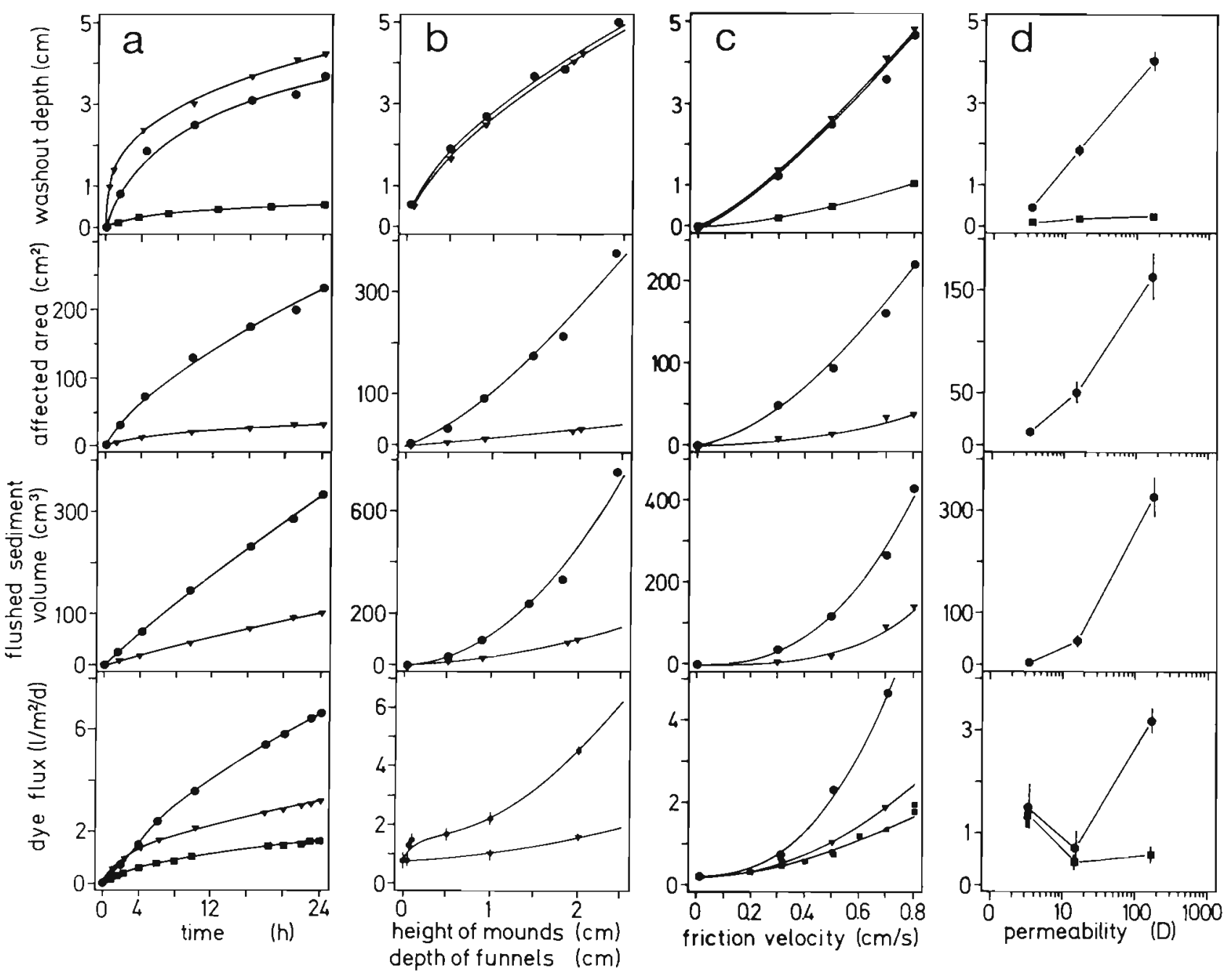

Fig. 4. Washout depth, surface area affected, sediment volume flushed and dye flux due to advective porewater flows associated

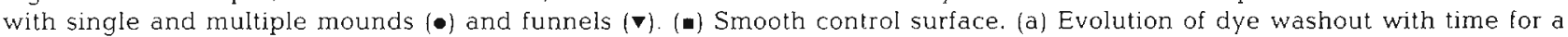
mound of $1.8 \mathrm{~cm}$ height and a funnel of $1.9 \mathrm{~cm}$ depth (u. $\left.=0.5 \mathrm{~cm} \mathrm{~s}^{-1}, \phi=2.2\right)$. (b) Effect of the size of mounds and funnels on dye washout. The steep increase in flux for the mounds smaller than $0.1 \mathrm{~cm}$ was caused by a larger diameter/height ratio compared to the larger mounds (flux measurements were done in separate experiments) $\left(u_{0}=0.5 \mathrm{~cm} \mathrm{~s}^{-1}, \phi=2.2, \mathrm{t}=24 \mathrm{~h}\right)$. (c) Impact of increasing friction velocity on the dye washout produced by a funnel of $0.9 \mathrm{~cm}$ depth and a mound of $0.9 \mathrm{~cm}$ height $(\phi=2.2, \mathrm{t}=$ $24 \mathrm{~h}$ ). (d) Dye washout produced by mounds of $1 \mathrm{~cm}$ height in sediments composed of diatom powder ( $\phi=6.6, K=3.4 \mathrm{D})$, fine sand $(\phi=2.2, K=15 \mathrm{D})$ and coarse sand $(\phi=0.5, K=168 \mathrm{D})\left(u .=0.3 \mathrm{~cm} \mathrm{~s}^{-1}, \mathrm{t}=24 \mathrm{~h}\right)$

level changes the roughness-related porewater flows, we exposed a sediment core $(60 \times 60 \times 15 \mathrm{~cm}, \phi=2.2$, $K=15 \mathrm{D})$ with funnels $(2 \mathrm{~cm}$ depth, $7 \mathrm{~cm}$ diameter), mounds $(2 \mathrm{~cm}$ height, $7 \mathrm{~cm}$ diameter) and 'crabs' $(0.5 \mathrm{~cm}$ thick, $2.5 \mathrm{~cm}$ diameter, $1 \mathrm{~cm}$ above surface) to unidirectional flow in a large recirculating flume $113 \mathrm{~m}$ length, $60 \mathrm{~cm}$ width, $35 \mathrm{~cm}$ height). At $30 \mathrm{~cm}$ water depth and a flow speed $\left(u=10 \mathrm{~cm} \mathrm{~s}^{-1}\right)$ generating a $u$. of $0.3 \mathrm{~cm} \mathrm{~s}^{-1}$, the bioroughness elements produced washout patterns similar to those observed in the small flume with $5 \mathrm{~cm}$ water depth. Lowering the water level to $5 \mathrm{~cm}$ caused an increase in the pressure gradient for a $2.5 \mathrm{~cm}$ mound by a factor of 1.2 to 1.3 (Fig. 7); for the bioroughness elements smaller than $2 \mathrm{~cm}$ the factors decreased to 1.1 and less. The sediment volume flushed per hour and associated dye fluxes grew linearly with the pressure gradient (Figs. 4a, b, c \& 6). To allow depth-independent comparison of the advective exchange processes recorded in our small flume at $5 \mathrm{~cm}$ water depth for the different roughness types, flushed sediment volumes and dye fluxes of the $2 \mathrm{~cm}$ mounds and the clam half-shells were divided by a factor of 1.2 and those of the crabs by a factor of 1.3.

In. all our sediment cores with biogenic surface structures, dye fluxes calculated from the final slope of the dye release curves exceeded those of the smooth control surfaces (Table 1, columns $2 \& 3$ ). With 7 pairs of smooth control runs vs surfaces modified by bio- 

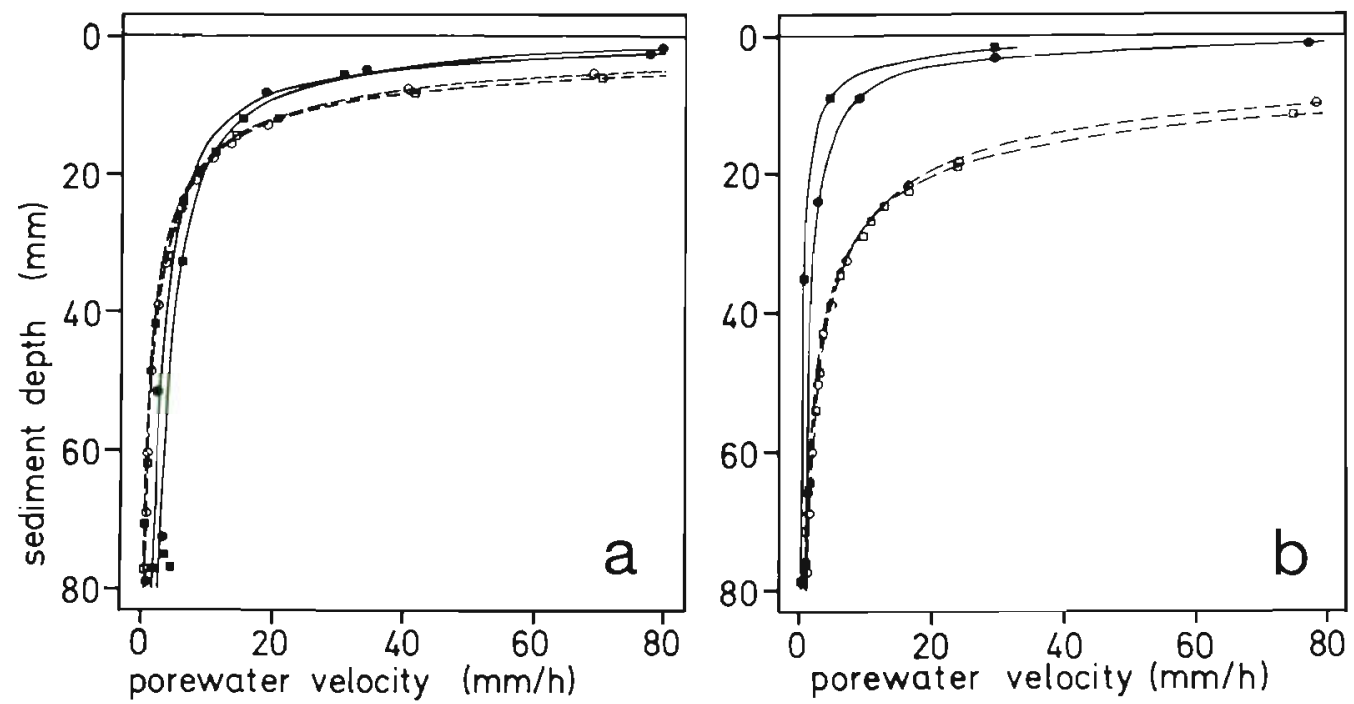

Fig. 5. Porewater velocities recorded beneath (a) 2 mounds of $2.5 \mathrm{~cm}$ height and (b) 2 funnels of $2 \mathrm{~cm}$ depth for flow creating a friction velocity $u$. of $0.7 \mathrm{~cm} \mathrm{~s}^{-1}$. Dashed lines and open symbols: velocities of downward-moving porewater; solid lines and solid symbols: velocities of upward-moving porewater
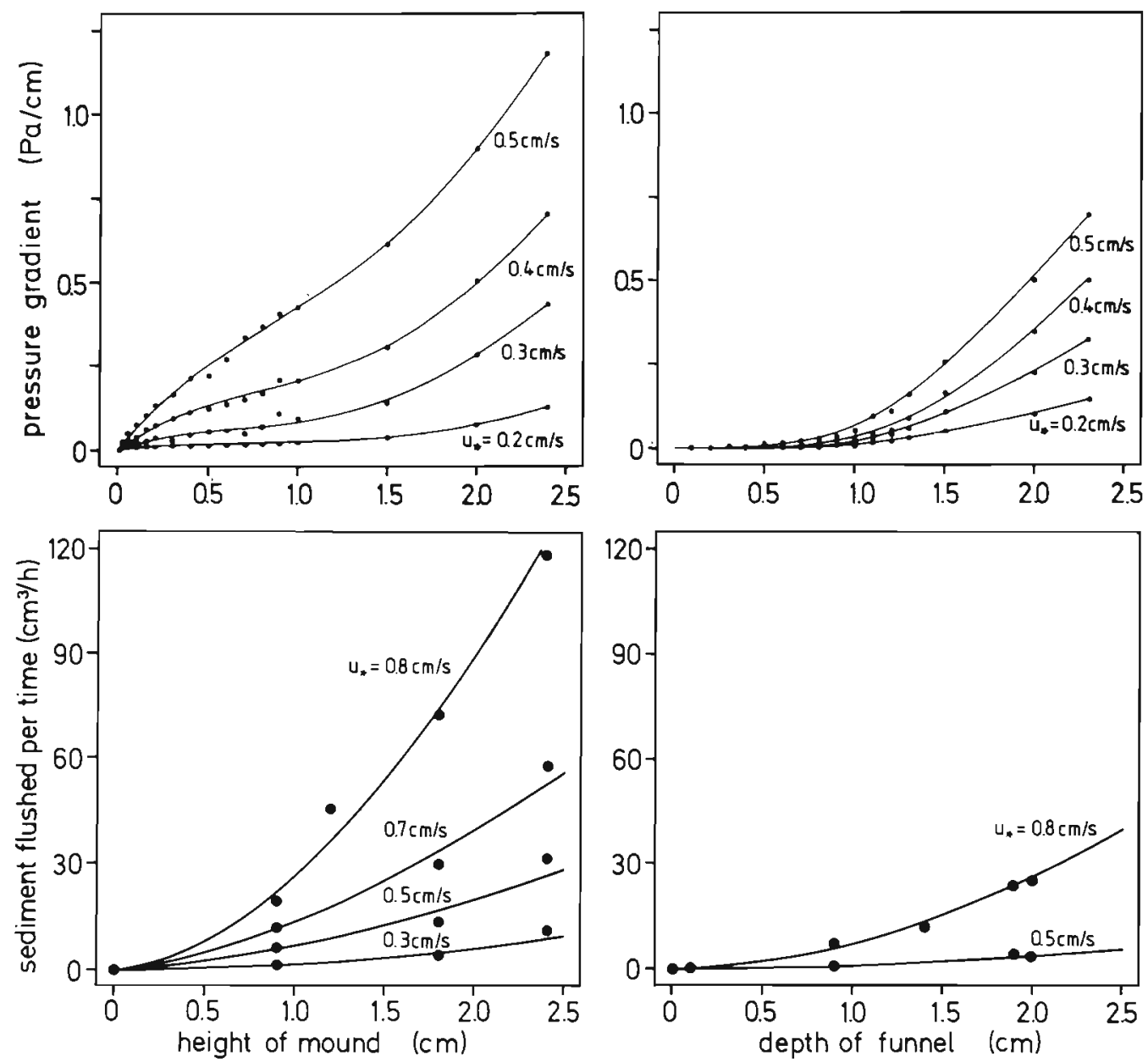

Fig. 6. Upper graphs: maximum pressure gradients caused by a mound and a funnel with increasing height and depth, respectively, at friction velocities of $u .=0.2,0.3,0.4$ and $0.5 \mathrm{~cm} \mathrm{~s}^{-1}$. Lower graphs: sediment flushed per unit time for funnels and mounds of different sizes at different friction velocities during the first $24 \mathrm{~h}$ time period (calculated using approximated linear growth for the sediment volumes flushed per time during the first $24 \mathrm{~h}$; compare Fig. $4 \mathrm{a}$ ) 


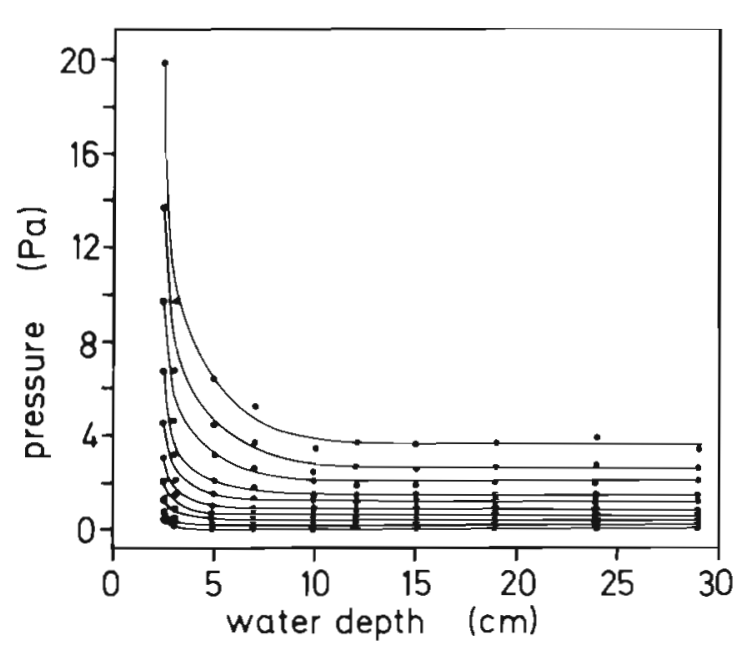

Fig. 7. Pressure differential between the tip of a mound $(2.5 \mathrm{~cm}$ height $)$ and the upstream sediment surface $(24 \mathrm{~cm}$ upstream) at different water depths for surface velocities of $2 \mathrm{~cm} \mathrm{~s}^{-1}$ (bottom curve) to $20 \mathrm{~cm} \mathrm{~s}^{-1}$ increased in $2 \mathrm{~cm} \mathrm{~s}^{-1}$ increments

roughness, the hypothesis that surfaces with biogenic structures produce the same dye flux as smooth sediment surfaces could be rejected at the $99 \%$ level (Sign test; Sachs 1978). The visible washout zones (Table 1 , columns $4 \& 5$ ) and the total volumes of dye released in 24. h runs (Table 1, column 7 ) confirmed this result. Interfacial dye flux from protruding mounds exceeded that from funnels of comparable size $(17$ mounds of $2 \mathrm{~cm}$ height $\mathrm{m}^{-2}: 4.5 \pm 0.11 \mathrm{~m}^{-2} \mathrm{~d}^{-1} ; 17$ funnels of $2 \mathrm{~cm}$ depth $\left.\mathrm{m}^{-2}: 1.6 \pm 0.1 \mathrm{I} \mathrm{m}^{-2} \mathrm{~d}^{-1} ; u \cdot=0.5, \phi=2.2\right)$. Mounds as small as $0.1 \mathrm{~cm}\left(17 \mathrm{~m}^{-2}\right)$ enhanced dye flux almost 2 -fold relative to the controls. The steep increase of the pressure gradient and dye flux for the surfaces with protrusions smaller than $0.1 \mathrm{~cm}$ (Fig. $4 \mathrm{~b}$ ) is explained by the larger diameter/height ratio of the very small sand mounds relative to the larger ones, which increased the magnitude of the associated pressure field. Increasing the height of the mounds, the depth of the funnels or the extent of the friction velocity resulted in an exponential growth of the dye fluxes (Fig $4 b, c$ ). Highest increases in dye flux, surpassing that of the smooth control sediments 7 -fold, were recorded for the core with Mercenaria campechiensis shells laying on the surface $\left(5.9 \pm 0.31 \mathrm{~m}^{-2} \mathrm{~d}^{-1} ; u .=0.5 \mathrm{~cm} \mathrm{~s}^{-1}, \phi=2.2\right)$, which can be attributed to the size and shape of the shells causing stronger flow obstruction and turbulence than the mounds of $2 \mathrm{~cm}$ height. The local flow field caused by protruding impermeable tubes and clam siphons flushed the porewater from relatively small sediment areas up- and downstream of the flow obstructions (Fig. 1), increasing dye flux approximately 2 -fold. The surface with scattered shell debris produced an enhancement of dye flux comparable to that of a surface with sediment ripples by an approximate factor of 5 .

Washout depth, the size of the surface area and the sediment volume affected by bioroughness-related advective porewater flows grew with increasing permeability of the substratum (Fig. 4d). Small mounds $(1 \mathrm{~cm}$ height) exposed to a friction velocity as low as $0.3 \mathrm{~cm} \mathrm{~s}^{-1}$ caused advective porewater flows and distinct washout zones even in sediment composed of diatom powder with $10 \mu \mathrm{m}$ grain size $(\phi=6.6)$ and a permeability of $3.4 \mathrm{D}$. The dye fluxes recorded for this sediment $\left(1.5 \pm 0.4 \mathrm{l} \mathrm{m}^{-2} \mathrm{~d}^{-1}\right.$ for $1 \mathrm{~cm}$ mounds; $\left.17 \mathrm{~m}^{-2}\right)$ exceeded those recorded for the fine sand as found in the smooth control core.

The dyed porewater release was not identical to the total amount of fluid flushed through the sediment per run time since the washed-out dyed pore fluid was continuously replaced by (undyed) intruding supernatant water. To account for this process, the water volume flushed through the sediment per day (Table 1 , column 6) was calculated by subtracting from the initial hourly fluxes measured in the cores with bioroughness ( $=$ flushing of the uppermost sediment layer, assumed to be primarily driven by advective processes) the final hourly dye flux of the smooth reference core lassumed to be the maximum flux possibly driven by diffusion) and multiplying the result by 24 . According to this estimate, up to 5-fold volumes of flume water were flushed through the upper layer of the sediment cores with biogenic topography relative to the smooth control surfaces (half-shells: $20.0 \pm$ $1.1 \mathrm{l} \mathrm{m}^{-2} \mathrm{~d}^{-1}$; smooth: $3.61 \mathrm{~m}^{-2} \mathrm{~d}^{-1}$ ).

\section{DISCUSSION}

Our results reveal an important pathway for interfacial solute exchange in permeable sediments. For bioroughness of scales smaller or equal to sedimentological topography, complex horizontal pressure patterns evolve at the sediment-water interface which drive water into the interstices of the sediments and pull porewater from deep layers to the surface. For the types of bioroughness and sediments we tested, interfacial solute fluxes, simulated by a conservative tracer, were tightly coupled to this porewater flow rather than driven merely by diffusion across the sediment surface. The advective processes in the pore space, caused by bioroughness elements present at common densities, affected the solute exchange over the entire sediment surface. Local pressure gradients created by microtopography as small as $700 \mu \mathrm{m}$ height caused advective porewater flows in sandy sediments which enhanced interfacial solute fluxes beyond that associated with Fickian diffusion. Our results reveal that 
advective porewater flow is still active for permeable, hydrodynamically smooth surfaces with roughness Reynolds numbers $\operatorname{Re}_{k_{*}}<5$ (Schlichting 1979). The laws of solute transfer from smooth, dissolving impermeable surfaces (Opdyke at al. 1987) thus cannot automatically be applied to smooth sediment surfaces. Instead bioroughness and permeability are critical parameters for sediment-water exchange processes since for soft sea floors, exposed to water currents below the erosion threshold, the microtopography is mainly of biological origin with the majority in the millimeter-size range (Laughton 1963, Heezen \& Hollister 1971, Swift et al. 1985).

Enhanced interfacial solute fluxes were also observed in smooth sediment beds with the bioroughness represented by animals placed on the surface. In our simulated crab experiments, the accelerating flow underneath the crab caused advective flows and washout patterns almost identical to a surface mound (this might also give an explanation as to why crabs often seem to stand still and yet are apparently feeding). The sand dollar Mellita quinquiesperforata has 5 radially oriented slots which extend from the lower (oral) to the upper (aboral) surface. In a current, water is drawn through these slots by the reduced pressure on the top (Vogel 1981). We propose that all epibenthic animals and demersal fish can be viewed as hydrodynamically active structures affecting, beyond their reworking activities, interfacial solute exchange in habitats with permeable sediments (see also Grant 1983, Vogel 1988).

Given the simplifying setup of our experiments (unidirectional flume flows, low water level, fresh water, sieved abiotic sand, dye as conservative tracer) we needed to demonstrate that our flux results can also be transferred to the natural environment. Geological, biological, chemical and physical processes produce in situ a variety of sediments with structural heterogeneity and high spatial and temporal variability. Our flume experiment represented a situation similar to that given for an intertidal sand flat during flooding tide. At low tide with the flat exposed, advective porewater transport is reduced to a minimum and the bioturbation of the benthic fauna ceases (Krüger 1966 , Reise 1985). The diffusive transport of solutes remains active in the pore space and, with the ongoing decomposition processes, increases the solute concentrations in the upper sediment layer. The incoming tide initially covers the flat with a shallow layer of relatively fast-moving water flowing over a permeable sediment surface with bioroughness. The lower the water level, the higher the flow velocity across the roughness elements and the associated pressure gradients will be (Fig. 7). Consequently, advective porewater flows due to bioroughness should be most pronounced during flooding and ebbing, with nutrient concentrations (ammonia, phosphate, silicate) in the water column highest when the water level is very low, as actually reported by Lillelund et al. (1985) and Asmus et al. (1990).

We conducted dye experiments in an intertidal sand flat on the west coast of northern Germany (Königshafen/Sylt, $55^{\circ} 02^{\prime} \mathrm{N}, 08^{\circ} 06^{\prime} \mathrm{E}_{;} \phi=1.2$, median grain size $=430 \mu \mathrm{m}$, porosity $=42 \%$ ) which provide circumstantial evidence that our laboratory results on fluxes can be linked to natural marine sediments. After injecting Rhodamine-WT into the pore space of the sandy intertidal sediments with small aggregations of mussels, washout zones were observed $15 \mathrm{~cm}$ deep, $20 \mathrm{~cm}$ diameter, $\mathrm{t}=6 \mathrm{~h}$ ) similar to those in the flume (Fig. 2a; compare with Fig. 2c, d showing flume runs). Two-dimensional flow at $15 \mathrm{~cm} \mathrm{~s}^{-1}$, generated by a chamber over a confined section of permeable intertidal sediment with bioroughness, likewise produced vertical mixing of the porewater. For runs lasting $6 \mathrm{~h}$, resulting nutrient profiles were characterized by lower concentrations with maxima extending over a wider depth range than outside the chamber (Huettel unpubl.).

Without bioturbation and boundary layer flow, the diffusion coefficient of dissolved silica at our field site ranged from $5 \times 10^{6}$ to $8 \times 10^{6} \mathrm{~cm}^{2} \mathrm{~s}^{-1}$ (Huettel 1988), which agrees with coefficients reported by Rutgers van der Loeff et al. (1984) $\left(3.5 \times 10^{6}\right.$ to $\left.12 \times 10^{6} \mathrm{~cm}^{2} \mathrm{~s}^{-1}\right)$ and Aller \& Yingst (1985) $\left(7 \times 10^{6} \mathrm{~cm}^{2} \mathrm{~s}^{-1}\right)$. Bioturbation of the local fauna increased the effective diffusion coefficient 8- to 9-fold (Huettel 1988). Rutgers van der Loeff et al. (1984) and Aller \& Yingst (1985) found similar increases in bioturbated sediments with factors ranging from 2 to 6 . Moderate boundary layer flow ( 6 to $10 \mathrm{~cm} \mathrm{~s}^{-1}$ ) enhanced the effective diffusion coefficient in the upper sediment layer $(0$ to $7 \mathrm{~cm}) 7$ - to 10 fold with no animals being present, while with bioturbation and flow, a 12- to 18-fold increase of the coefficient was recorded (Huettel 1988). Even higher increases up to a factor of 100 were reported from sites where a combination of strong currents, wave activities and topography caused flushing of the upper sediment layer (Riedl et al. 1972, Vanderborght et al. 1977. Rutgers van der Loeff 1981).

Based on our observations and the literature data, we propose that solute exchange processes in permeable sediments extend vertically through 3 layers: (1) an upper layer $(0$ to $5 \mathrm{~cm}$ ), where advective porewater flushing related to local pressure gradients created by surface topography or accelerating boundary layer flows is the dominant pathway coupled to (2) a layer ( 5 to $20 \mathrm{~cm}$ ) where bioturbation (if present) is the major process for solute transport, followed by (3) a lower layer where Fickian diffusion determines solute trans- 


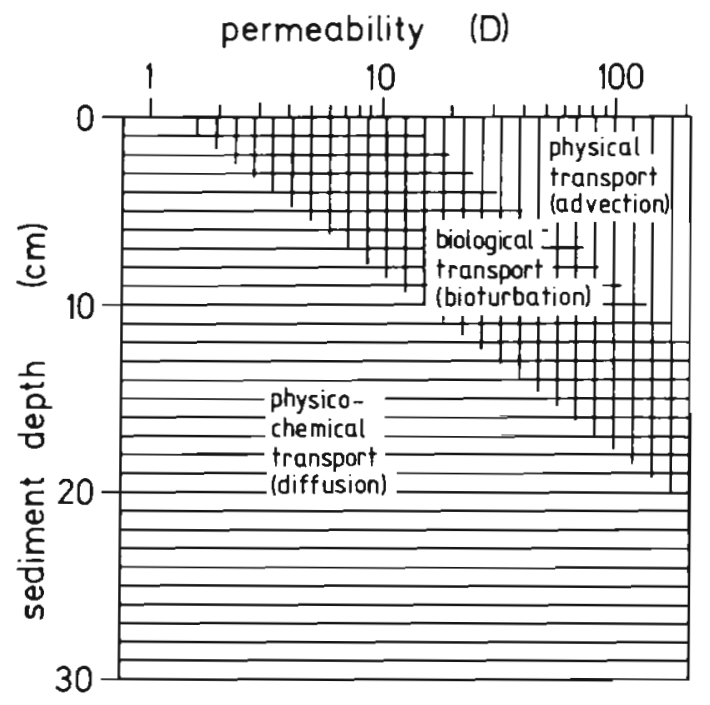

Fig. 8. Schematic of the proposed depth range of the 3 major solute transport processes (diffusion, bioturbation, physical advection) in marine sediments of different permeabilities. Note that diffusion as well as physical advection (which includes bioroughness effects) are active in the zone of bioturbation

port (Fig. 8). For intertidal sandy sediments we suggest as a rough approximation that the effective diffusion coefficient for a conservative tracer increases by a factor of 5 to 10 per layer beyond the diffusive value. With diminishing permeability of the sediment, the layers dominated by bioturbation and diffusian transport move upwards and the thickness of the hydrodynamically flushed layer decreases (Figs. 4d \& 8). Bioturbation and bioroughness extend the range of advective processes towards sediments with lower permeability, accelerating interfacial solute exchange above the limits of diffusive transport.

The key factor for pressure-driven porewater exchange is permeability. Approximately $40 \%$ of the shelf is covered by permeable sediments (Riedl et al. 1972, Ott 1988j but permeable sea beds have also been found in the deep sea, in areas with strong bottom currents (Sayles \& Jenkins 1982, Driscoll \& Tucholke 1983). We can anticipate this process even in originally impermeable sediments, when the presence of abundant macrofauna leads to a 'secondary permeability' by its burrows, tubes and bioturbation or by surface layers of fecal pellets, shell debris and other skeletal remains, e.g. diatom shells (Risk \& Moffat 1977, White et al. 1985). In densely populated areas, reworking and fecal pellet formation can fluidize the upper layer of muddy sediments (Rhoads \& Young 1970). Ray \& Aller (1985) stressed the importance of relict burrows for sediment-water solute exchange in the deep sea, a typical case of bioroughness-related solute release. In sediments with insignificant permeability, biorough- ness may enhance interfacial solute exchange by enlarging the surface area for the exchange processes (Gundersen \& Jørgensen 1990). Surface tracks of benthic organisms can double the boundary roughness and pelletization can increase the roughness of the sediment surface sufficiently to disrupt the viscous sublayer (Nowell et al. 1981, Grant et al. 1982). Eckman (1985) observed an increase in bacterial colonization at the sediment-seawater interface caused by a protruding animal-tube mimic, an effect which we think can also be attributed to the roughness-related solute release from the sediment. At very high abundances of bioroughness elements (e.g. extensive areas with protruding polychaete tubes, seagrass meadows) the water flow between the protruding structures is reduced and a new boundary layer develops which may alter the effect of the microtopography on interfacial fluid exchange (Nowell \& Church 1979, Luckenbach 1986).

Roughness-related pressure gradients draw porewater from layers as deep as $15 \mathrm{~cm}$ to the surface, linking nutrient and toxicant cycles of deep sediment layers to the water column (Lee \& Swartz 1980. Swartz \& Lee 1980). In contrast to muddy sediments where diffusion acts mainly in a vertical direction (Berner 1976), pressure-driven porewater flows in permeable sediments have an equally important horizontal component since the same volume of water intruding into the porespace has to leave the sediment elsewhere. While transport of oxygen and sulfate into the sediment enhances organic matter decomposition and nitrification (Jørgensen \& Sørensen 1985, Enoksson \& Samuelsson 1987), shifts in redox potential and $\mathrm{pH}$ associated with upwelling anoxic porewater cause release of redox-sensitive substances such as phosphate and heavy metals (Balzer 1986). The 3-dimensional pattern of the advective porewater flows increases the surface area of the redox-potentialdiscontinuity (RPD) layer (Berner 1980, Ott \& Novak 1989), with ensuing formation of microzones and microlayers enhancing the metabolic activity of the upper sediment horizon.

The microzonation, produced by the interstitial flow patterns, is not static but changes with type and distribution of the bioroughness (Smith et al. 1986) and the magnitude of the ambient water currents. The life cycles and behavior of benthic life forms produce a complex spatial and temporal pattern of bioroughness (Reise 1979, Rhoads \& Boyer 1982, Volkaert 1987, Graf 1989). In our experiments we demonstrate instantaneous interstitial fluid flow as soon as water starts moving over sediment microtopography, tightly coupling the pattern of flushing and upwelling sediment zones with the persistence of the roughness structures. Mobility and tolerance to oxygen and hydrogen sulfide 
can be expected from microorganisms living in these sediments, which could explain the overlap in the sequence of electron acceptors used by microorganisms with increasing depth (Canfield 1991). Interstitial meiobenthic organisms respond to changes in the benthic boundary layer flow, either ascending or moving deeper into the sediment (Hogue \& Miller 1981, Palmer \& Molloy 1986, Armonies 1988), demonstrating the close coupling of the interstitial environment in permeable sediments and water currents. The variety of microenvironments created by the spatial and temporal variability of the advective porewater flows provides numerous ecological niches (Ott \& Novak 1989) which may explain the diversity of meiofauna communities and the patchiness of their distribution (Thistle 1979, Reise 1981, Jumars \& Eckman 1983).

We conclude that bioroughness, generating porewater flows in response to boundary layer flows, is an important factor controlling interfacial solute fluxes and interstitial chemical and biological processes in permeable sediments. With transport velocities of advective porewater flows surpassing diffusive transport by a factor of up to 1000 in our experiments, advection acts in the pore space as a conveyor belt connecting deeper sediment layers to the surface, allowing oxidation agents to reach anoxic depth and reduced substances to ascend to the surface. Resulting microenvironments and microlayers may form zones of retreat, survival and spreading of aerobic and microaerophilic lifeforms and increase the metabolic reaction potential of the sediment. Roughness-related advection in the porespace can thus be viewed as a structuring process producing chemical gradients and microzones in space and time, which is counteracted by the tendency of diffusion to generate an equal distribution of dissolved substances. Bioroughness-related advective processes thus play a key role in permeable sediments.

Acknowledgements. This research was supported by a grant from the Deutsche Forschungsgemeinschaft to $\mathrm{M}$. Huettel as part of the Foreign Visitors Exchange Program of the University of South Florida. We express our thanks to Prof. W. Noodt (Kiel University, Germany) who helped us realize this project. We also appreciate the helpful suggestions and constructive criticisms of K. Reise, S. Forster, W. Bowles, E. Holmes and 2 anonymous reviewers.

\section{LITERATURE CITED}

Aller, R. C. (1982). The effect of macrobenthos on chemical properties of marine sediment and overlaying water. In: McCall, P. L., Tevesz, M. J. S. (eds.) Animal-sediment relations. Plenum Press, New York, p. 53-105

Aller, R. C., Yingst, J. Y. (1985). Effects of the marine deposit feeders Heteromastus filiformis (Polychaeta), Macoma baltica (Bivalvia), Tellina texana (Bivalvia) on averaged sedimentary solute transport, reaction rates, and microbial distributions. J. mar. Res. 43: 615-645

Armonies, W. (1988). Hydrodynamic factors affecting behavior of intertidal meiobenthos. Ophelia 28: 183-193

Asmus, H., Asmus, R. M., Reise, K. (1990). Exchange processes in an intertidal mussel bed: a Sylt-flume study in the Wadden Sea. Ber. Biol. Anst. Helgoland 6: 1-79

Balzer, W. (1986). Forms of phosphorus and its accumulation in coastal sediments of Kieler Bucht. Ophelia 26: 19-37

Berner, R. A. (1976). The benthic boundary layer from the viewpoint of a geochemist. In: McCave, I. N. (ed.) The benthic boundary layer. Plenum Press, New York, p. 33-55

Berner, R. A (1980). Early diagenesis - a theoretical approach. Princeton University Press, Princeton

Blackburn, T. H. (1986). Nitrogen cycle in marine sediments Ophelia 26: 65-77

Cacchione, D. A., Drake, D. E., Field, M. E., Tate, G. B. (1987). Sea-floor gouges caused by migrating gray whales off northern California. Cont. Shelf Res. 7: 553-560

Canfield, D. E. (1991). Organic carbon diagenesis in marine sediments. Abstracts of papers for the 1991 annual meeting of the American Society of Limnology and Oceanography. Bedford Institute of Oceanography, Halifax

Denny, M.W. (1988). Biology and the mechanics of the waveswept environment. Princeton University Press, Princeton

Driscoll, M., Tucholke, B. E. (1983). Seafloor zonation in sediment texture and benthic megafauna in the Hebble (High Energy Benthic Boundary Layer Experiment) area. EOS Trans. Am. geophys. Union 64: 729-735

Eckman, J. E. (1985). Flow disruption by animal-tube mimic affects sediment bacterial colonization. J. mar. Res. 43: 419-435

Enoksson, V., Samuelsson, M.-O. (1987). Nitrification and dissimilatory ammonium production and their effects on nitrogen flux over the sediment-water interface in bioturbated coastal sediments. Mar. Ecol. Prog. Ser. 36: 181-189

Fenchel, T. (1970). Studies on the decomposition of organic detritus derived from the turtle grass Thalassia testudinum. Limnol. Oceanogr. 15: 14-20

Graf, G. (1989). Benthic-pelagic coupling in a deep-sea benthic community. Nature 341: 437-439

Grant, J. (1983). The relative magnitude of biological and physical sediment reworking in an intertidal community. J. mar. Res. 41: 673-689

Grant, W. D., Boyer, L. F., Sanford, L. P. (1982). The effects of bioturbation on the initiation of motion of intertidal sands. J. mar. Res. 40: 659-677

Grassle, J. F., Sanders, H. L., Hessler, R. R., Rowe, G. T., McLean, T. (1975). Pattern and zonation: a study of the bathyal megafauna using the research submarine Alvin. Deep Sea Res. 22: 457-481

Gundersen, J. K., Jørgensen, B. B. (1990). Microstructure of diffusive boundary layers and the oxygen uptake of the sea floor. Nature 345: 604-607

Gust, G. (1988). Skin friction probes for field applications. J. geophys. Res. 93: 14121-14132

Gust, G., Harrison, J. T. (1981). Biological pumps at the sediment-water interface: mechanistic evaluation of the alpheid shrimp Alpheus mackayi and its irrigation pattern. Mar. Biol. 64: 71-78

Heezen, B. C., Hollister, C. D. (1971). The face of the deep. Oxford University Press, New York

Hogue, E. W., Miller, C. B. (1981). Effects of sediment microtopography on small-scale spatial distributions of meiobenthic nematodes. J. exp. mar. Biol. Ecol. 53: 181-191

Howard, J. D., Mayoll, T. V., Heard, R. W. (1977). Biogenic sedimentary structures formed by rays. J. sedim. Petrol. 47: $339-346$ 
Huettel, M. (1988). Zur Bedeutung der Macrofauna für die Nährsalzprofile im Wattsediment. Ber. Inst. Meeresk. Kiel 182: $1-203$

Huettel, M. (1990). Influence of the lugworm Arenicola marina on porewater nutrient profiles of sand flat sediments. Mar. Ecol. Prog. Ser. 62: 241-248

Huettel, M., Gust, G. (1992). Solute release mechanisms from confined sediment cores in stirred benthic chambers and flume flows. Mar. Ecol. Prog. Ser. 82: 187-197

Jørgensen, B. B., Sorensen, J. (1985). Seasonal cycles of $\mathrm{O}_{2}$, $\mathrm{NO}_{3}$, and $\mathrm{SO}_{4}$ reduction in estuarine sediments: the significance of an $\mathrm{NO}_{3}$ reduction maximum in spring. Mar Ecol. Prog. Ser. 24: 65-74

Jumars, P. A., Eckman, J. E. (1983). Spatial structure within deep-sea benthic communities. In: Rowe, G. T (ed.) The sea VII: deep sea biology. Wiley and Sons, New York, p. $99-451$

Krüger, F. (1966). Messungen der Pumptätigkeit von Arenicola marina L. im Watt. Helgoländer wiss. Meeresunters. 11: $70-91$

Laughton, A. S. (1963). Microtopography. In: Hill, M. N. (ed.) The sea III. Wiley, New York, p. 437-473

Lee, H., Swartz, R. C. (1980). Contaminants and sediments, Vol. 2, Biological processes affecting the distrubution of pollutants in marine sediments, Part 2, Biodeposition and bioturbation. Ann Arbor Science Publishers, Ann Arbor, p. $555-606$

Lillelund, K., Berghahn, R., Dierking, R. (1985). Changes in the phosphate content of water in a tidal channel through the Wadden Sea near Nordstrander Bight (Eastern North Sea) during a tidal cycle. Int. Revue ges. Hydrobiol. 70 : $101-112$

Luckenbach, M. W. (1986). Sediment stability around animal tubes: the roles of hydrodynamic processes and biotic activity. Limnol. Oceanogr. 31.779-787

Malan, D. E., McLachlan, A. (1991). In situ benthic oxygen fluxes in a nearshore coastal marine system: a new approach to quantify the effect of wave action. Mar. Ecol. Prog. Ser. 73:69-81

Nowell, A. R. M., Church, M. (1979). Turbulent flow in depth limited boundary layer. J. geophys. Res. 84: 4816-4824.

Nowell, A. R. M., Jumars, P. A., Eckman, J. E. (1981). Elfects of biological activity on the entrainment of marine sediments. Mar. Geol. 42: 1.33-153

Opdyke, B. N., Gust, G., Ledwell, J. R. (1987). Mass transfer from smooth alabaster surfaces in turbulent flows. Geophys. Res. Lett. 14: 1131-1134

Ott, J (1988). Meereskunde. Einführung in die Geographie und Biologie der Ozeane. Verlag Eugen Ulmer, Stuttgart

Ott, J. A., Novak, R. (1989). Living at an interface: meiofauna at the oxygen/sulfide boundary of marne sediments. In Ryland, J. S., Tyler, P. A. (eds.) Reproduction, genetics and distribution of marine organisms. Olsen and Olsen. Fredensborg, p. 415-422

Palmer, M. A., Molloy, R. M. (1986). Water flow and the vertical distribution of meiofauna: a flume experiment Estuaries 9: 225-228

Pemberton, G. S., Risk, M. J., Buckley, D. E. (1976). Supershrimp: deep bioturbation in the stratt of Canso, Nova Scotia. Science 192: $790-791$

Ray, A. J., Aller, R. C. (1985). Physical irrigation of relict burrows: implications for sediment chemistry. Mar. Geol 62: $371-379$

Reichardt, W. (1988). Impact of bioturbation by Arenicola marina on microbiological parameters in intertidal sediments. Mar. Ecol. Prog. Ser. 44: 149-158

Reise, K. (1979). Spatial configurations generated by mobile benthic polychaetes. Helgoländer wiss. Meeresunters. 32: $55-72$

Reise, K. (1981). High abundance of small zoobenthos around biogenic structures in tidal sediments of the wadden sea. Helgoländer wiss. Meeresunters 34: 413-425

Reise, K. (1985). Tidal flat ecology. Ecological Studies 54. Springer-Verlag, Berlin

Rhoads, D. C., Aller, R. C., Goldhaber, M. B. (1977). The influence of colonizing benthos on physical properties and chemical diagenesis of the estuarine seafloor. In: Coull B. C. (ed.) Ecology of marine benthos. University of South Carolina Press, Columbia, p. 113-138

Rhoads, D. C., Boyer, L. F. (1982). The effect of marine benthos on physical properties of sediments: a successional perspective. In: McCall, P. L., Tevesz, M. J. S. (eds.) Animal-sediment relations: the biogenic alteration of sediments. Plenum Press, New York, p. 3-52

Rhoads, D. C.. Young, D. K. (1970). The influence of depositfeeding organisms on sediment stability and community trophic structure. J. mar. Res. 28: 150-178

Richardson, M. D., Briggs, K. B., Young, D. K. (1985). Effects of biological activity by abyssal benthic macroinvertebrates on a sedimentary structure in the Venezuela Basin. Mar. Geol. 68: 243-267

Riedl, R. J., Huang, N., Machan, R. (1972). The subtidal pump: a mechanism of interstitial water exchange by wave action. Mar. Biol. 13: 210-221.

Riedl, R. J., Machan, R. (1972). Hydrodynamic patterns in lotic intertidal sands and their bioclimatological implications. Mar. Biol. 13: 179-209

Risk, M. J., Moffat, J. S. (1977). Sedimentological significance of fecal pellets of Macoma baltica in the Minas Basin, Bay of Fundy. J. sedim. Petrol. 47: 1425-1436

Rutgers van der Loeff, M. M. (1981). Wave effects on sediment water exchange in a submerged sand bed. Neth. J. Sea Res. 15: 100-112

Rutgers van der Loeff, M. M., Anderson, L. G., Hall, P. O. J., Iverfeldt, A., Josefson, A. B., Sundby, B., Westerlund, S. F. G. (1984). The asphyxiation technique: an approach to distinguishing between molecular diffusion and biologically mediated transport at the sediment-water interface. Limnol. Oceanogr. 29: 675-686

Sachs, L. (1978). Angewandte Statistik. Springer-Verlag, Berlin Sayles, F. L., Jenkins, W. J. (1982). Advection of pore fluids through sediments in the equatorial East Pacific. Science 217: $245-248$

Schlichting, G. H. (1979). Boundary layer theory, 7th edn. McGraw-Hill, New York

Sleath, J. F. A. (1984). Sea bed mechanics. John Wiley \& Sons, New York, p. 57-96

Smith, C. R., Jumars, P. A., DeMaster, D. J. (1986). In situ studies of megafaunal mounds indicate rapid sediment turnover and community response at the deep sea-floor. Nature 323: 251-253

Swartz, R. C., Lee, H. (1980). Contaminants and sediments, Vol. 2, Biological processes affecting the distribution of pollutants in marine sediments. Part 1, Accumulation, trophic transfer, biodegradation and migration. Ann Arbor Science Publishers, Ann Arbor, p. 533-553

Swift, S. A., Hollister, C. D., Chandler, R. S. (1985) Close-up stereo photographs of abyssal bedforms on the Nova Scotia contmental rise. Tech. Rep. Woods Hole oceanogr. Inst. 21: 1-21

Taghon, G. L., Nowell, A. R. M., Jumars, P. A. (1984). Transport and breakdown of fecal pellets: biological and sedimentological consequences. Limnol. Oceanogr. 29: $64-72$ 
Thistle, D. (1979). Harpacticoid copepods and biogenic structures: implications for deep-sea diversity maintenance. In: Livingston, R. J. (ed.) Ecological processes in coastal and marine systems. Plenum Press, New York, p. $217-231$

Vanderborght, J. P., Wollast, R., Billen, G. (1977). Kinetic models of diagenesis in disturbed sediments (1). Mass transfer propertıes and silica diagenesis. Limnol. Oceanogr. 22: 787-793

Vogel, S. (1981). Life in movıng fluids: the physical biology of flow. Willard Grant, Boston

Vogel, S. (1988). How organisms use flow-induced pressures Am. Scient. 76: 28-34

This article was submitted to the editor
Volkaert, F. (1987). Spatial pattern of soft-bottom polychaeta of Nova Scotia, Canada. Mar. Biol. 93:627-639

Wainright, S. C. (1990). Sediment-to-water fluxes of particulate material and microbes by resuspension and their contribution to the planktonic food web. Mar. Ecol. Prog. Ser. 62: 271-281

Wheatcroft, R. A. (1991). Conservative tracer study of horizontal sediment mixing rates in bathyal basin, California borderland. J. mar. Res. 49: 565-588

White, D. C., Smith, G. A., Stanton, G. R. (1985). Biomass, community structure, and metabolic activity of the microbiota in benthic marine sediments and sponge spicule mats. Antarct. J U.S. 19: 125-126

Manuscript first received: August 17, 1992

Revised version accepted: November 4, 1992 